\title{
Community College Learning Resources Centers at the Crossroads: Illinois, a Case Study
}

\section{Eileen Dubin and Linda Bigelow}

In 1985 a survey of public Illinois community college learning resources centers was conducted. The study revealed a great variety in the organization, staffing, collections, and services provided by LRCs. The LRCs have entered resource sharing in a variety of ways and have experienced a large growth in interlibrary loan transactions and the use of telecourses. The survey revealed, however, that 64 percent have book collections of less than 50,000 volumes and that twenty of the forty-two have periodical collections that are below ACRL standards for community colleges. Also, LRC progress in developing automation for housekeeping and resource sharing has been piecemeal and lags behind the introduction of automation in other library sectors in Illinois.

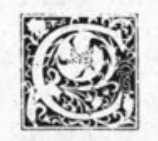

ommunity colleges, like other institutions of higher education, recently have been buffeted by rapid technological change and severe social pressures, including changes in enrollment patterns. More generally they are in the midst of a transformation that may impact their missions, goals, and organizational structures. They are in need of leadership that can anticipate economic, social, demographic, and technological change and bring together the skills, flexibility, and persistence for meeting changing educational requirements. ${ }^{1}$ At the same time they are still experiencing the effects of the high inflation so prominent in the early 1980 s and a shift in public priorities that has, in real terms, reduced federal funds and, in many cases, state appropriations. Accordingly, community college learning resource centers (LRCs) are also struggling to adapt to these changing needs under conditions of financial constraint.

As a result of technological changes, LRCs are transforming their roles as collection centers into centers for accessing information. ${ }^{2}$ They are being linked into communication networks that allow them to reach beyond their own walls to identify and retrieve information stored in a variety of ways in a variety of institutions. The challenges implied by these tasks reach into all corners of the library profession as it currently exists. Every function of the library has been touched, and the tasks of every professional have been and will continue to be transformed. Apart

Eileen Dubin is director, Library Services, Stockton State College, Pomona, New Jersey 08240. Linda Bigelow is associate dean of Instruction-Learning Resources, McHenry County College, Crystal Lake, Illinois 60014. 
from these intellectual resources, substantial capital investment will be needed to bring the new technologies into operation, to retrain professionals who are required to provide traditional services in new ways, and to acquire the means of offering new services.

LRCs are faced with these challenges while continuing to support the academic and community missions of their colleges. Currently these institutions provide a broad range of educational programs and services. In Illinois, as in California, New York, Florida, Texas, Maryland, and North Carolina, each public community college has a comprehensive mission. ${ }^{3}$ Each has a liberal arts and sciences program to prepare students who wish to transfer to four-year colleges and universities or pursue lifelong learning; vocational and technical programs for job training, retraining, or upgrading of skills; and preparatory, developmental, and remedial programs to furnish students with secondary school certification, upgraded skills, or help necessary for success in postsecondary education. With the increase in nontraditional learners, there has also been a substantial rise in developmental education courses and a quiet revolution in instructional methodology. This methodology includes computerassisted instruction and other forms of delivery to enhance literacy and learning. In addition, all public community colleges are committed to public service programs through adult continuing education. ${ }^{4}$

Late in 1984 the Illinois Association of College and Research Libraries/Illinois Board of Higher Education Ad Hoc Committee on Community Colleges conducted a survey to determine the current condition and foreseeable needs of Illinois public community college LRCs. The survey queried the LRCs about their programs and resources; their hours of service; the size and professional status of their staffs; the nature, size, and use of their collections; their unique collections; the kinds of services they provide; the use of automation and telecommunications; and the kinds of resource-sharing networks in which they participate. In particular, the survey was designed to help identify ways in which community college LRCs might strengthen resource sharing.

Survey forms were distributed to fifty LRCs. Forty-two were returned for a response rate of $84 \%$. Additional community college demographic data were obtained from the Data Book on Illinois Higher Education 1984 and 1985 and from the Illinois Community College Board (ICCB) (see table 1).

Enrollment data in table 1 show that over the last decade almost 50 percent of students enrolled in higher education in Illinois have been on community college

TABLE 1

ENROLLMENT AND FINANCIAL DATA FOR ILLINOIS COMMUNITY COLLEGES 1976-85

\begin{tabular}{llcllc}
\hline \hline *Year & $\begin{array}{c}\text { Total } \\
\text { Enrollment }\end{array}$ & $\begin{array}{c}\text { \% of College } \\
\text { Population in } \\
\text { Ilinois CC }\end{array}$ & $\begin{array}{l}\text { tOperating } \\
\text { Expenditures }\end{array}$ & $\begin{array}{c}\text { tLRC } \\
\text { Support }\end{array}$ & $\begin{array}{c}\text { \% of Total } \\
\text { Educational Budget }\end{array}$ \\
\hline 1976 & 326,058 & 48.9 & $232,498,276$ & $11,223,134$ & 4.8 \\
1977 & 329,947 & 49.2 & $257,938,640$ & $11,601,900$ & 4.5 \\
1978 & 322,367 & 48.7 & $279,463,060$ & $11,903,467$ & 4.3 \\
1979 & 323,652 & 48.7 & $292,853,498$ & $12,691,751$ & 4.3 \\
1980 & 359,047 & 50.3 & $328,425,957$ & $14,223,430$ & 4.3 \\
1981 & 388,369 & 52.0 & $374,893,852$ & $16,146,584$ & 4.3 \\
1982 & 387,822 & 52.1 & $427,776,579$ & $17,677,994$ & 4.1 \\
1983 & 356,643 & 50.1 & $450,794,856$ & $18,399,122$ & 4.1 \\
1984 & 361,187 & 50.5 & $478,834,148$ & $19,410,203$ & 4.1 \\
1985 & 339,782 & 48.7 & $486,170,303$ & $19,919,438$ & 4.1 \\
\hline
\end{tabular}

"Illinois Board of Higher Education, "Enrollment Trend Data," Data Book on Illinois Higher Education, 1985 , p.83.

tIllinois Community College Board, "Data and Characteristics of the Illinois Public Community College System 1976-1985," various editions, plus information through phone conversation with ICCB staff.

fIllinois Board of Higher Education, "Audited Expenditures for Illinois Public Community Colleges by Functional Classification," Data Book on Illinois Higher Education, 1984 and 1985, p. 248 and 236. 
campuses.

Funding for the LRCs in Illinois declined from 4.8 percent of operational budgets in 1976 to 4.1 percent in 1985 . Overall operating appropriations increased almost 18 percent more than LRC appropriations.

Indeed, while LRC appropriations increased between FY76 and FY85 from $\$ 11,223,134$ to $\$ 19,919,438$, or by 17.75 percent, they lagged substantially behind the rate of inflation.

\section{MISSION AND SCOPE}

While responses to the survey question on mission and scope varied greatly in length and detail, all the institutions described their missions in terms of providing "services and material resources required to meet the informational, learning and development needs" of their students, faculty, administrators, and district residents. They also identified themselves by reference to a multiplicity of services offered. These include collection development, bibliographic instruction, reference, audiovisual services, production of video materials, maintenance of cable TV operations, film rentals, production of graphics and photographs, support of telecourses, microcomputer labs, and aid to handicapped students and those needing remedial assistance. Few of them indicated how changing technologies fit in with their missions or reported on possible partnerships for instructional purposes.

\section{HOURS OF SERVICE}

LRC hours of service averaged 66 per week, with a range of 42.5 to 82.75 . Just over half of the LRCs provided some Saturday hours, while only seven were open on Sunday, reflecting the nonresidential nature of community college student bodies.

\section{STAFF}

While most of the LRCs have full-time administrators, in some the administrator also serves as librarian.

Respondents were asked to report only those members of their staffs engaged in library and audiovisual activities. The number ranged from a low of 2 to a high of 43.5. Nine LRCs reported no administrators, 6 no professional librarians, and 9 no

\section{LRC STAFF - FTE}

\section{Administrators}

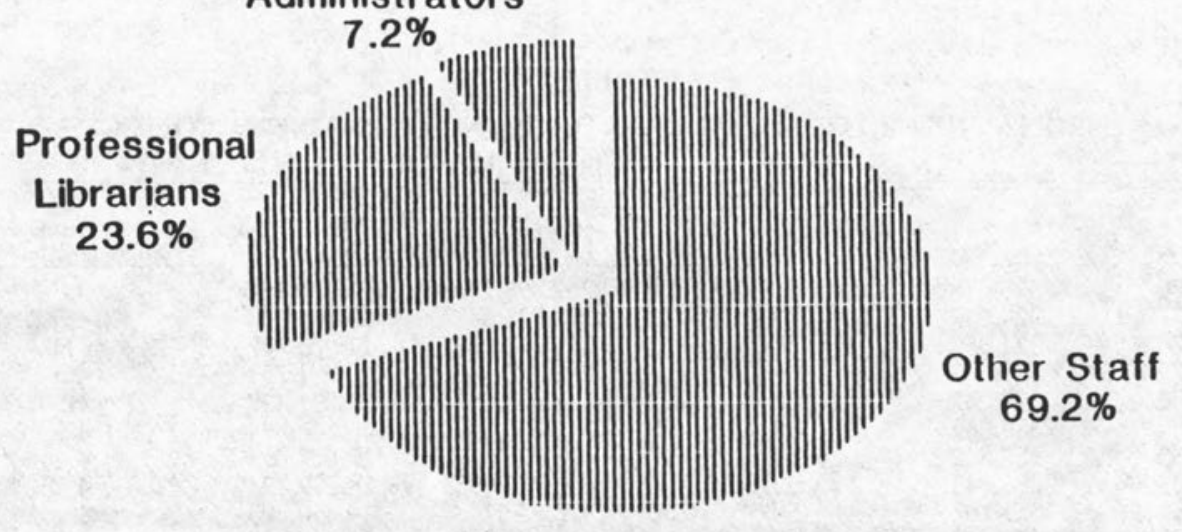

\section{FY 1983-84}


classified/technical staff members. Overall staffing increased 3 percent from FY81 to FY84, with most of the increase in the classified staff (variously referred to as classified, clerical, and paraprofessional). Figure 1 shows the current percentage of LRC staffs in each of the three categories.

\section{COLLECTIONS}

The collections of the responding LRCs totaled 2,635,577 items, of which 673,852 were nonprint and 1,961,725 were print materials. Book collections ranged from a low of 5,400 to a high of 115,063 volumes, although twenty-seven of the forty-two LRCs (or 64 percent) had under 50,000 volumes. The number of volumes increased 15 percent from FY81 to FY84 (see table 2).

Periodical collections ranged from a low of 79 to a high of 790 titles (see table 3). Periodical subscriptions for the thirty-six LRCs providing statistics decreased 6 percent from FY81 to FY84.

TABLE 2

BOOK COLLECTIONS BY SIZE: FY 1984

\begin{tabular}{lc}
\hline \hline Number of Volumes & No. LRCs \\
\hline 29,000 or less & 7 \\
$30,000-39,999$ & 12 \\
$40,000-49,999$ & 8 \\
$50,000-59,999$ & 4 \\
$60,000-69,999$ & 4 \\
$70,000-79,999$ & 2 \\
$80,000-89,999$ & 1 \\
$90,000-99,999$ & 1 \\
$100,000-116,000$ & 2 \\
NA & 1 \\
Total & 42 \\
\hline
\end{tabular}

TABLE 3

PERIODICAL SUBSCRIPTIONS: FY 1984

\begin{tabular}{lc}
\hline \hline $\begin{array}{c}\text { Number of } \\
\text { Subscriptions }\end{array}$ & No. LRCs \\
\hline 99 or less & 2 \\
$100-199$ & 2 \\
$200-299$ & 12 \\
$300-399$ & 7 \\
$400-499$ & 4 \\
$500-599$ & 7 \\
$600-699$ & 2 \\
$700-799$ & 4 \\
NA & 2 \\
Total & 42 \\
\hline
\end{tabular}

One way to look at the LRC periodical collections is by reference to the 1979 ACRL quantitative standards for periodicals in community college LRCs. Taking into account FTE enrollments, ACRL identifies the number of subscriptions that qualify a collection as minimal or good. ${ }^{6}$ Translating Illinois data into the ACRL format, one finds that twenty of the Illinois institutions have below-standard collections; seventeen, minimal collections; and only three, good collections (see table $4)$.

\section{CIRCULATION}

Forty LRCs circulated 1,402,096 books and media in FY84, an increase of 21 percent over FY81 for those LRCs providing comparative statistics.

\section{INTERLIBRARY LOAN}

Interlibrary loan transactions in LRCs more than doubled from FY81 to FY84. In FY81 LRCs lent 8,914 items, while in FY84 they lent 20,299 items. In FY81 LRCs borrowed 16,118 items, while in FY84 they borrowed 33,042 items. It is significant that all but one of the top ten lenders and top ten borrowers participated in a shared database such as Online Computer Library Center (OCLC), C L Systems, Inc. (CLSI), Library Computer Systems (LCS), or Data Phase.

The dramatic increase in interlibrary loan activity shows a willingness on the part of community college LRCs to contribute to resource sharing. Most of them are currently net borrowers from institutions outside the LRC system, demonstrating their dependence upon external resources.

\section{SERVICES}

The LRCs provide a wide range of services: all provide reference services and LRC orientations/tours; all but one distribute audiovisual equipment. Other services most frequently cited included inhouse production services, (graphics, transparencies, audio and video production, audio and video duplication, sound/slide production, lamination, photography, signs, posters, dry mounting, and printing); bibliographic instruction; 
TABLE 4

ACRL QUANTITATIVE STANDARDS FOR PERIODICALS SUBSCRIPTIONS AND

PERIODICAL COLLECTIONS OF ILLINOIS COMMUNITY COLLEGES

\begin{tabular}{|c|c|c|c|c|c|c|c|}
\hline \multirow[b]{2}{*}{ FTE Enrollments } & \multicolumn{2}{|c|}{ Standards } & \multicolumn{5}{|c|}{ Schools Reporting } \\
\hline & Level & $\begin{array}{c}\text { No. of } \\
\text { Periodicals }\end{array}$ & No. & B & $\mathrm{M}$ & G & NA \\
\hline UNDER 1,000 & $\mathrm{M}$ & 200 & 2 & 1 & 1 & 0 & 0 \\
\hline $1,000-3,000$ & $\begin{array}{l}\mathrm{G} \\
\mathrm{M} \\
\mathrm{G}\end{array}$ & $\begin{array}{l}300 \\
300 \\
500\end{array}$ & 22 & 12 & 7 & 2 & 1 \\
\hline $3,000-5,000$ & $\stackrel{M}{\mathrm{G}}$ & $\begin{array}{l}500 \\
700\end{array}$ & 11 & 4 & 5 & 1 & 1 \\
\hline $5,000-7,000$ & $\stackrel{M}{G}$ & $\begin{array}{l}700 \\
800\end{array}$ & 3 & 2 & 1 & 0 & 0 \\
\hline $\begin{array}{l}7,000-8,000^{\star} \\
8,000-9,000 \\
9,000-10,000 \\
11,000-12,000\end{array}$ & & & $\begin{array}{r}1 \\
0 \\
1 \\
2 \\
42 \\
\end{array}$ & $\begin{array}{r}0 \\
0 \\
1 \\
0 \\
20\end{array}$ & $\begin{array}{r}1 \\
0 \\
0 \\
2 \\
17 \\
\end{array}$ & $\begin{array}{l}0 \\
0 \\
0 \\
0 \\
3\end{array}$ & $\begin{array}{l}0 \\
0 \\
0 \\
0 \\
2 \\
\end{array}$ \\
\hline
\end{tabular}

Legend:

$\mathrm{B}=$ Below Standard

$\mathrm{M}=$ Minimal

$\mathrm{G}=$ Good

$\mathrm{NA}=$ Not Available

*For enrollments over 7,000, the ACRL Standard minimal (M) is 5 periodicals per 1,000 FTE; good (G) is 30 per 1,000 .

online database searching; typewriters for public use; services to the handicapped; microcomputer labs; telecourses; developmental courses; study skills centers; GED; English as a second language; testing centers; and copier service. The diversity of these services reflects the dynamic and changing environment in which the LRCs operate.

\section{AUTOMATION}

Twenty, or less than half, of the fortytwo responding LRCs subscribed to the OCLC cataloging database. Many of these had not converted their holdings into machine-readable form and did not subscribe to such OCLC subsystems as acquisitions, interlibrary loan, and serials control. A number of LRCs used automated circulation systems, but they varied in kind and did not interface. Outside of cataloging and circulation, the other major impact of automation was in word processing.

\section{TELECOMMUNICATIONS}

Illinois public community colleges are just beginning to use various telecommunication options, including television broadcast capabilities of low-power transmitters, instructional television fixed ser- vices (ITFS), ${ }^{8}$ and ultra-high frequency (UHF); radio broadcast capabilities of AM, FM, and subcarriers; land-line links and cable TV; and teleconferencing.

\section{TELECOURSES}

Community colleges have been particularly successful in offering telecourses. Twenty-six colleges offered from two to twenty telecourses each semester. Enrollment, as shown in Figure 2, climbed steadily from 1981 to 1984 , resulting in an enrollment increase of 203 percent.

At least half of the Illinois community colleges offered telecourses. Videotapes of the telecourses are placed in the LRC and in various off-campus sites such as public libraries and extension centers. Telecourses may also be telecast over local cable stations or on public broadcast stations. In order to provide as much flexibility as possible, many of the colleges provide their students with both the nonbroadcast and broadcast options.

\section{NETWORKING AFFILIATIONS}

Public community college LRCs in Illinois have developed very active networks for cooperative activities through three regional consortia: the Northern Illinois Learning Resources Cooperative 
(NILRC), the Mid-Illinois Learning Resources Cooperative (MILRC), and the Southern Illinois Learning Resources Cooperative (SILRC). The goals of the three "Rocks" are to strengthen the skills and knowledge of LRC personnel through inservice training and workshops; to improve the cost-effectiveness of member LRCs through such cooperative purchasing agreements as telecourse leasing/purchasing, film-to-tape transfers, off-air recording rights, and reference works; and to exchange information through meetings, publication of an Illinois Learning Resources Personnel Directory, and working committees such as the Telecommunication Advisory Group, Instructional Television Fixed Services/Satellite Distribution Committee, Illinois Community College Board Evaluation
Committee, and Staff Development Committee. Apart from the City Colleges of Chicago, which do not participate, all but two Illinois public community college LRCs belong to one or more of the three "Rocks."

NILRC, MILRC, and SILRC come together under the umbrella organization of the Learning Resources Commission of the Illinois Council of Community College Administrators (ICCCA) and through this commission have expanded regional cooperative efforts and communication links into significant statewide activities. NILRC recently approved the hiring of a full-time executive director, as the work of the cooperative has expanded beyond what members can accommodate on a volunteer basis. This action required a dues increase and caused some loss of member-

\section{TELECOURSE ENROLLMENTS}

\section{(Headcount)}

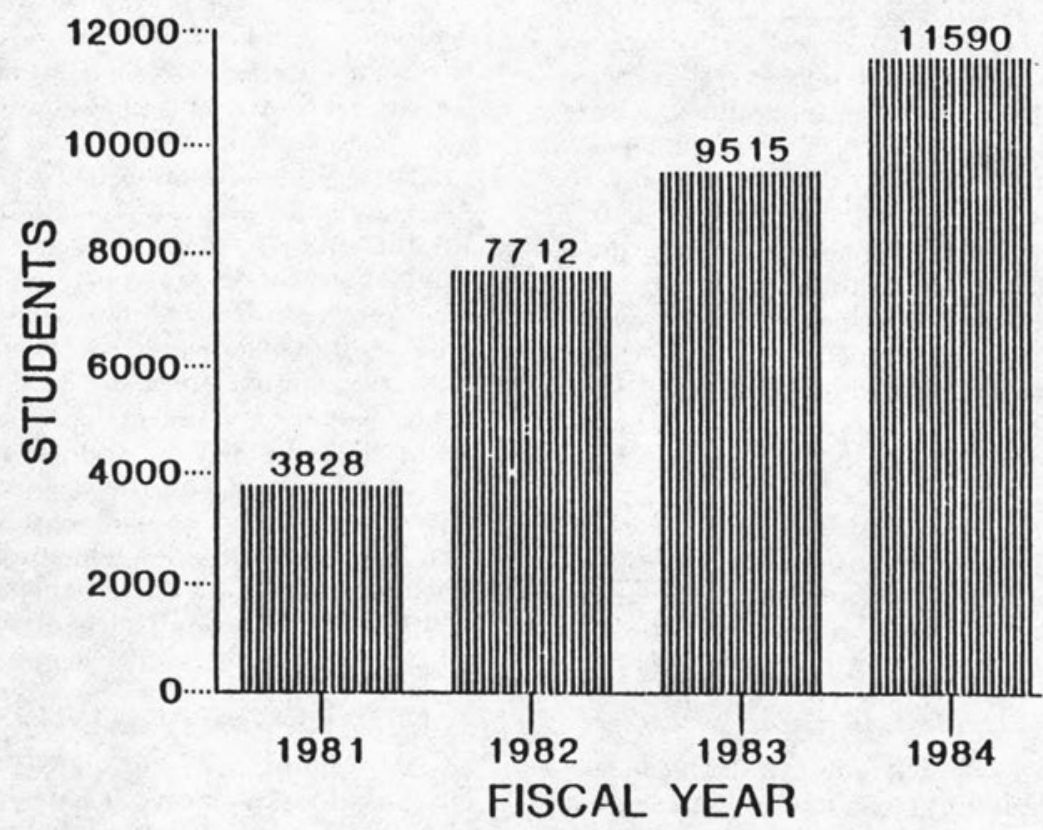


ship.

Community college LRCs have also formed strong links with their communities by actively participating in the regional public library systems of the Illinois State Library and Information Network (ILLINET). Through ILLINET some are sharing in automated databases, most are participating in interlibrary loan activities, and many are receiving the benefits of staff development workshops, aid for the blind and physically handicapped, film rentals, materials delivery systems, consulting services, cooperative purchasing, union lists, and back-up reference assistance.

The City Colleges of Chicago have formed their own system and share resources with each other on a formal as well as an informal basis. They also are affiliated with the Chicago Public Library System. Other consortia to which LRCs belong are based upon special interests or regional affiliations. These networking activities represent a dynamic that over time may lead to greater coordination and resource sharing throughout the state.

\section{CURRENT STRENGTHS OF COLLECTIONS}

LRC collections in Illinois reflect the diverse curricula of their institutions. Frequently cited collection strengths were in nursing and allied health, agriculture, women's studies, and criminal justice. Some subjects for which there are unique collections are nondestructive testing, clock and watch repair, legal technology, fashion design, orchestral music scores, and plastics and polymers.

\section{PERCEIVED NEEDS IN RESOURCE SHARING}

The survey asked LRC respondents to identify what they believed to be additional resource sharing needs. Their recommendations fell into six categories:

1. Develop an interconnected online catalog throughout the state by interfacing existing online systems.

2. Actively implement existing legislation for multitype regional library systems that will include all types of libraries within geographic regions.

3. Improve online union lists of print and nonprint materials, including reference collections, serials, special collections, media materials, computer software, and telecourses.

4. Devise less expensive communications systems.

5. Institute cooperative production of media materials, including telecourses.

6. Expand programs for cooperative purchasing.

A number of the institutions recognized that additional funding would be required to accomplish the purposes they described.

\section{CONCLUSIONS}

Public community college LRCs in Illinois have much in common. In recent years they have experienced a marked growth in circulation and interlibrary loan transactions and in the use of telecourses. They have engaged in resource sharing in a variety of ways and through a variety of organizations. However, progress in developing automation for housekeeping and resource sharing has been piecemeal and lags behind the introduction of automation to other library sectors in Illinois.

In a recent article on LRC automation, Barbara Dohrman and Jack Weiss of the Elgin (Illinois) Community College LRC, attribute LRC automation lag to budget constraints and the low value placed on automation by community colleges. ${ }^{10}$ The limited automation and apparent disinterest threaten to leave Illinois community colleges in a backwater that ultimately may compromise their ability to fulfill their academic missions. Right now, for instance, the Illinois State Library is creating an online catalog that, when completed, will contain over three million titles. LRCs without adequate automation will be unable to tap into this system. They will be unable to employ network resources and services that will become increasingly important in the face of limited budgets, burgeoning knowledge, and changing student clients (and needs). They will, as a consequence, be illequipped to function in the academic mar- 
ketplace. To remedy this situation at least three steps seem essential:

1. LRC directors must convince their college administrators to place greater priority than now exists on automating their LRCs and linking them into existing and potential networks.

2. LRCs must enter more fully into net- works that keep them abreast of new technologies and trends in statewide activities.

3. LRCs, with Illinois Community College Board support, must develop specific proposals for resource sharing that attract the support of existing public and private funding agencies.

\section{REFERENCES AND NOTES}

1. Richard Alfred and others, ed., Emerging Roles for Community College Leaders (San Francisco: Jossey-Bass, 1984).

2. "Guidelines for Two-year College Learning Resources Programs (Revised): Part One," College $\mathcal{E}$ Research Libraries News 43, no.1:5 (Jan. 1982).

3. In Illinois there are thirty-nine community college districts with fifty-two colleges. Thirty-seven of these colleges are governed by locally elected boards of trustees. In Chicago, the nine community colleges are governed by a locally appointed board of trustees, while State Community College in East St. Louis has a board of trustees appointed by the governor of Illinois. With the exception of East St. Louis, each district has local taxing power. The thirty-nine districts encompass 97 percent of the state's population. An effort to find data on community college LRCs in states having similar two-year institutions has been unsuccessful. Specific reports have been located for particular years, providing scattered data insufficient for comparative purposes.

4. In fact, in 1983, 378,393 students in Illinois were enrolled in these noncredit programs ("Enrollment Indicators Brief," AACJC Letter Supplement, May 1, 1984). In addition, Illinois community colleges enroll 55 percent of entering freshmen in all higher education [AAC]C Letter, no.107:2 (Sept. 4, 1984)]. The age of community college students ranges widely. Well over 50 percent are twenty-five years or older, and 70 percent attend college on a part-time basis (Illinois Community College Board "General Information" brochure, Oct. 1985).

5. While totally comparable data are not readily available, the Illinois Board of Higher Education's "Higher Education Price Index for Books and Periodicals" shows that the cost of these materials nearly doubled between FY76 and FY84, while its adjustment for library materials price increases built into higher education appropriations amounted to less than half of the sum required to match inflation. ("Chancellor's Report \#9," Aug. 1, 1985, p.39).

6. "Draft: Statement on Quantitative Standards for Two-Year Learning Resources Programs," College \& Research Libraries News 40, no.3:71 (Mar. 1979). While the periodical standard can be compared, the way in which the ACRL standard for "written materials" is composed prevents comparison with the book holdings of Illinois community college LRCs.

7. See Doris Cruger Dale, "Computers in Community College Libraries," Community and Junior College Libraries 3, no.2:17-26 (Winter 1984). Dale's findings parallel those of the survey reported in this article.

8. ITFS is a locally based, high-frequency television service used for educational programming. It was created in 1962 by the FCC for use by private and public nonprofit institutions.

9. Ralph G. Steinke, "Learning Resources Cooperation: It Can Be Successful," Library Trends 33, no.4:473-85 (Spring 1985).

10. Barbara K. Dohrman and Jack A. Weiss, "Automation and the Learning Resources Center," Library Trends, 33, no.4:459-71 (Spring 1985). 


\section{NEW!}

ABSTRACTS AND INDEXING ON TYPESET FICHE

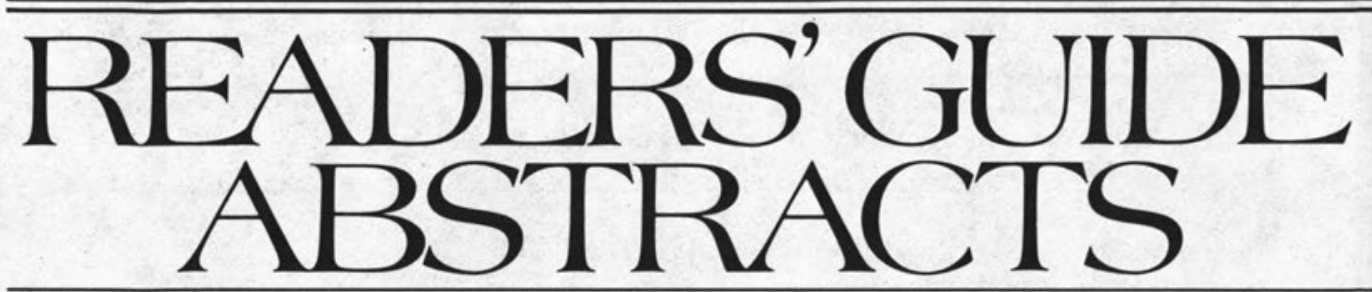

The Wilson Company now offers high-quality abstracts for its best-known index,

Readers' Guide to Periodical Literature. Combining abstracts with indexing on easy-to-read typeset microfiche, Readers' Guide Abstracts makes research faster, easier, and more efficient than ever before.

\section{QUALITY INFORMATION IN A QUALITY PACKAGE}

High-Quality Abstracts

Well-written, accurate abstracts accompany the entry for each article indexed.

\section{Readers' Guide Indexing}

The full cross-reference structure and indexing for each of the more than 180 periodicals covered in Readers' Guide are offered in Readers' Guide Abstracts.

\section{Readability}

Readers' Guide Abstracts retains the format and typography of Readers' Guide, using bold face and italic type to distinguish the components of each entry.

\section{Easy to Display and Store}

Each cumulation is delivered

already filed in a durable display kit.

\section{Currency}

Readers' Guide

Abstracts is updated and cumulated eight times each year.
Retrospective Coverage

Indexing and abstracting coverage beginning September 1984 is cumulated with recent material in every issue of Volume I (1986).

\section{MICROFICHE READER AND READER/PRINTER AVAILABLE}

As a special offer to Readers' Guide Abstracts subscribers, Wilson is offering high-quality Bell + Howell microfiche readers and reader/ printers at reduced rates.

The Micro Design 895 (48x) microfiche reader is available to subscribers at $\$ 188$, non-subscribers pay $\$ 288$.

The Micro Copy $10(48 \mathrm{x})$, reader/ printer is available to subscribers at $\$ 399$; non-subscribers pay $\$ 499$.

\section{SPECIAL OFFER!}

No-Risk Trial Subscription

With your no-risk trial subscription to Readers' Guide Abstracts, you will be invoiced after the initial shipment, but payment is not due for 30 days. If you are not completely satisfied, simply return the invoice marked "Cancelled" and there will be no financial obligation. The fiche you have received prior to cancellation are yours to keep.

Your subscription to Volume I (1986) of Readers' Guide Abstracts brings you eight cumulations issued approximately every six weeks, beginning May 1986. Each cumulation of Volume I contains retrospective coverage beginning in September 1984. An annual subscription is priced at $\$ 675$ U.S. and Canada, $\$ 750$ other countries.

To Order Call Toll-Free 1-800-367-6770

In New York State, call 1-800-462-6060;

in Canada, call collect 212-588-8400.
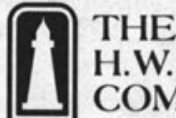

THE H.W. WILSON COMPANY 950 University Avenue

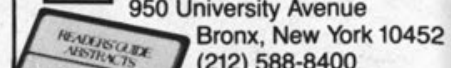

